\title{
Negotiating Identity in Democratic Society : The Internet and The New Public Sphere of Salafi-Niqabi Women
}

\author{
Yuyun Sunesti ${ }^{1}$, Noorhaidi Hasan ${ }^{2}$ and Muhammad Najib Azca ${ }^{3}$ \\ ${ }^{1}$ Inter-Religious Studies, Universitas Gadjah Mada \& Sociology Department, Universitas Sebelas Maret \\ ${ }^{2}$ Universitas Islam Negeri Sunan Kalijaga \\ ${ }^{3}$ Universitas Gadjah Mada \\ yuyun_sunesti@staff.uns.ac.id
}

Keywords: Salafi-niqabi, negotiation, online-offline public sphere, salafi manhaj

\begin{abstract}
The discovery of the internet has significantly changed the way people live the life in the contemporary world. People are increasingly easy to connect and build a network with the outside world that they have never seen before. The Internet is also used for a variety of needs, from searching and disseminating information, to the need for market promotion and expressing their personal life. The internet has been also argued in the course of enhancing the democratic nature of the world as it facilitates people to be having more freedom to talk and express. This also applies to Salafi-Niqabi women who have been known to be very close to the outside world. The internet has changed their previous ways of life that is very restrictive, closed to the outside world and always seen as the voiceless group. This paper analyzes the internet usage of young Salafi-Niqabi women in Surakarta and their negotiation with their strict salafi manhaj in their everyday life. Using narrative inquiry approach by applying in-depth interview and participative observation method, this paper discovers that while salafi manhaj requires them to strictly limit their appearance in the public space, the online space has created an alternative space to facilitate them to exist beyond their offline world.
\end{abstract}

\section{INTRODUCTION}

After the political and monetary crisis of 1997 and 1998, Indonesia was in the era of reformation where the nation is on the transition from authoritarianism to a more democratic government. The period following the fall of the New Order was believed to bring freedom of expression to Indonesian citizens and the realization of transparency in bureaucracy, decentralization, local autonomy as well as a stronger civil society role. In the context of Islam, this era of democracy provides fresh air for the Islamic community in expressing their religiosity. The fruits of this democratic transition are some of the increasing political Islam (Porter 2002; Riddell 2002), the Islamic movement (Alimi 2014) and symbolic Islam or Islamism (Sakai \& Fauzia 2014). Bruinessen (2014) calls this period as a 'conservative turn' which began in 2005 identified with the marginalization of the mainstream Islamic view.

One of the developments of what Bruinessen called the conservative turn of the reform era is the emergence of fundamentalist groups that offer an exclusive Islam that explicitly identifies itself as a salafi. Started in Indonesia since the mid-1980s, the group demonstrates strict religious symbols in their apparitions, such as wearing long Arabian robes, trousers over ankles and long beards for men, and wearing veils for women. Hasan (2007) stated that they live in small and exclusive communities and tend to be separated from the open society around them.

The impact of the exclusive and different way of life from the average community is the emergence of stigmas about salafi groups, especially ones aimd to the women. Salafi women are often seen as women who have no agency or are limited in expressing their individual rights. In addition, they are also often considered as an extremist group because of the way they dress resembles them to the radical fundamentalist women who are often featured in the media. These negative views may arise since the lack of openness of the wider community around them, especially those from the outside.

In the period of current Indonesian democracy where more people are having more access to 
involve in public activities, giving their voices and interact with many more people and contribute to more public needs, the existence of niqabi have been questioned. Their options to limit their interaction in public spaces and hide their voices in private spaces invited scholars to have better understand regarding their agency, contribution as well as women power in their environment.

This paper analyses the agency of salafi niqabi women, how they carry out their agency in their hidden world and look for the possibility of their involvement as active players in the power relations they face. The research finds that the current Indonesia democratic society provides easy access to development technology especially the internet as new interaction and communication media, which is resulting to supply more space and medium for this salafi niqabi to be active in their 'public' spaces.

\section{METHODS}

Based on the problems, objectives, approaches and methods of analysis, this research is included in qualitative research, which is research that produces findings that cannot be achieved by using statistical procedures or by quantitative means (Ghony and Almanshur 2012). While the type of qualitative research used in this study is narrative research (narrative inquiry). According to Clandinin and Conelly (2000: 20), narrative inquiry is a way to understand and investigate an experience through collaboration between researchers and participants in a place or place and in their interactions with their environment. Through this research, the life story of the informant will be explored, understood and then interpreted to gain more comprehensive understanding of the related story.

\subsection{Data Collecting}

There are two types of sources data that will be used to analyze the topic in this research, there are primary data and secondary data. Primary data sources directly provide data to researchers, meanwhile secondary data sources are sources that do not directly provide data to researchers. The source for the primary data sources in this study were provided directly from salafi-niqabi women in Surakarta. Secondary data will be collected from documents produced by the salafi community such as books, magazines, pamphlets and other internal documents. In addition, secondary data can also be derived from salafi religious leaders and also salafi husbands who have a close relationship in the process of power relations in the community.

\subsection{Sampling Techniques}

The Salafi women community is a very difficult community to approach because of their tight restrictions on social interaction in public spaces. Therefore, this qualitative research combines three sampling techniques at the same time. There are random sampling, purposive sampling and snowball sampling. Purposive sampling is a technique of sampling with the source data under certain considerations where informants have been known. In this regard, some important female figures in the salafi community became informants of this research. The next sample was chosen through random sampling, in which the salafi women the researchers met accidentally, as in salafi study and elsewhere became informants. Next snowball sampling, i.e. as the snowball which when rolled over the longer the larger, the next informant obtained through the recommendation of the previous informant and so on until the number of informants is quite representative.

Data collection techniques for this research were conducted through in-depth interviews of salafiniqabi women and refined by participatory observation of the activities of these women and their communities.

\section{RESULTS AND DISCUSSIONS}

The study of salafi movements has been a concern of scientists since the last fifteen years; precisely after the 9/11 World Trade Centre attacks that occured in the United States. The movement of salafi as a global movement has been widely discussed comprehensively by scientists. Studies by several scientists include Teitelbaum (2000), Fandi (2001), Roy (2002), Al-Rasheed (2002), Commins (2006) and Turner (2014) focusing on the linkage of salafism with other Islamic movements in the Middle East, Europe and North America. A fairly comprehensive literature on the global salafi is a collection of studies conducted by Roel Meijer (2009). Several other studies focusing on salafi studies as a global movement were also undertaken by Sedgwick (2012), Lauzière (2016) and Byman \& Gold (2012). However, most of these studies have looked at Salafism as a transnational Islamic movement in relation to terrorism and radicalism and used a security studies approach (Ali, 2016; 
Armborst, 2009; Amghar 2007; Hegghammer 2006; Hasan 2006; and Lia 2007).

In Indonesia, the study of the Salafi movement has highlighted the development of movements, politics movement, criticism of their religious doctrine and challenges to democracy in Indonesia (Hasan 2007, 2005; Jahroni 2015; Hishamam 2010; Wahid, 2014; Bruinessen, 2017). As a religious movement that began to globalize and attract many followers, Hasan (2011) saw a significant increase in the number of salafi schools in Indonesia after the New Order era. In line with the increase in salafi schools, Iqbal (2017) also finds increasing interest of young Indonesians who are interested in following the path of salafism in the last five years. Unfortunately, despite the emergence of research on Salafi movement groups in Indonesia, research focusing on salafi women is still very limited.

Research conducted by Inge (2016) is a research representative enough to describe the life of salafi women who live in the secular world of the West, especially in England. Through ethnographic methods, Inge explores how salafi women in London adapt to British secular culture and maintain their beliefs and way of life according to their salaf manhaj. Although also already emerging, the study of salafi women in Indonesia is also still limited. The existing study of salafi women is dominated by findings that reinforce the argument about the passivity and subordination of salafi women. Research conducted by Astuti (2010), Hanifah (2013), Tarawiyah, Merlin (2010), Jannah, Hapsari 2011, Sabrina 2014, Mahanani 2016 and Nisa 2012 \& 2013, largely reinforce the argument about the limited salafi women's agency due to the exclusive and closed way of life from the outside world. The study of this theme is quite comprehensive in Indonesia written by Nisa (2012). By focusing on young salafi women in Yogyakarta and Makasar, Nisa underlines that amid its limitations, salafi women also have a strategy to negotiate while living under a non-Islamic state.

Indonesian democracy has provided a 'fresh wind' for Indonesian citizens to express their identity, to access public spaces equally for both men and women, and voices their opinions. Religious identities which have been passively appeared in public spaces for long period during New Order Era, gain important momentum to emerge in the reformation era, including the growth various conservative religious groups such as salafism. This brings about the growing emergence of religious symbols in public such as niqab.
Although many women have been benefited from this democratic society, such as expressing their identity or ideas to providing more freedom to easily involve in public spaces, salafism has still had very strong restriction to limit women in their interaction in public spaces. Several requirements are given when women intended to enter the public sphere. Usuallay, they are suggested to wear niqab and avoid ikhtilat (intermingling between men and women). Therefore, many niqabis prefer to spend their time in their private spaces or doing activities with their female counterpart since it is limited for them to have broader communication with the opposite sex. As a result, their everyday life has not been much exposed to the public.

The development of technology, especially the discovery of the internet has dramatically changed people's life, including these niqabis. While they are very strict in following salafi manhaj in limiting their appearance and involvement in many activities in offline public sphere, they could find more freedom to express their voices and activities through the online platform. Here, they actively shared their daily activities, opinions and religious advices through online media such as WhatsApp, Facebook, and telegram. In this online space, they found a 'public sphere' where they are hidden in the offline sphere. In Nisa's (2013:3) views, the relation of niqabis and the internet is by "creating their own secluded virtual public sphere".

\subsection{The Internet for Niqabis}

While niqabis are tended to close and limit their interaction in the public sphere, they create their own public sphere on the internet. Internet provides endless possibilities for its users, depend on what the necessity they're aiming for, including for the niqabis. There are many functions of the internet for niqabis. Firstly, the internet is an alternative source to access religious information beside of offline learning they regularly follow such as daurah and regular religious sermons. As we all know, internet is one of the vast source to look for any kind of information and knowledge, including what the niqabis looking for. The internet, even, has had higher portion to access information for niqabis as it provides easier access and can be done without require them to be out of home. YouTube, Facebook, Twitter and WhatsApp groups has become popular applications they access since it provides them to be able to listen and read religious preaching and articles. 
Secondly, the internet is used to be a da'wah platform to share their belief and ideology to other people. Many informants state that usually they use Facebook and WhatsApp group to share Islamic contents based on salafi manhaj. There, they usually post various contents based on Quran and hadith and discuss them when there are other users who interested and raise some related questions. However, they limit the friendship in the online media only with female users as they stated to protect their izzah (value)--though for some cases some men had been also appeared in some contact lists without their knowledge.

The third activity which niqabis do in the online sphere is for business. Besides as a platform to share information and knowledge, internet is frequently used to start a business since its capabilities to reach massive number of people easily. Through Facebook and WhatsApp groups, they sell various goods such as hijab, abaya, foods, shoes, herbal medicine and even herbal tonic for male and female sexual medicines. In this online media, niqabis widen their buyers to be not only local customers, but also overseas. Naturally this activity could empowering the economy and give them more opportunity to lead more prosperous life spiritually and physically.

Furthermore, while in offline sphere, their daily activities have been closed and private. Yet in online media, some niqabis have been actively sharing their everyday activities to the public online sphere. Some niqabis have been routinely posts their call to return to Quran and Sunnah paths. Another niqabi was routinely posts their daily activities including their work load, their children as well as emotions they are facing, just like any other civil society recently do. In this point, even though their everyday life was very hided, it is more accessible in the online sphere than ever before.

\subsection{Niqabi and Identity Negotiation}

Under salafi manhaj, niqabi has a strict rule to be a devout salafi woman. Limiting their interaction in public and mostly run their role as wives in the private space as the manhaj suggested have been the principle or the way they live their life. But this surely shifted with the existence of the internet. In fact, the internet has brought about a new realm for niqabis to experience a public in their private sphere. The internet has facilitated them to express their voices, idea and opinion, while in the offline sphere it is limited. Even though not as a whole, online sphere surely has a new world bringing them to enjoy what democratic society offers which is freedom to talk and to express.

Although not presenting the freedom as democracy intends it to, the niqabis and the internet have brought a 'liberal' sense of talk and expression in different meaning. Nisa (2013: 3) argues that while scholars found the internet contributed to democratization and development of civil society in Indonesia, the usage of the internet for niqabi has tended to maintain their subcultures which are not presenting a 'liberalizing' path in common democracy terminological understanding.

In this point, even though internet has brought some beneficial for the niqabis where they could taste and experience the nature of freedom, it is still limited for them to maintain their existence and to exemplify their claim to be the true belief. Therefore, though it does not met the full democracy values offering such as equality, freedom of speech and expression, the internet has brought niqabis' sense of this freedom in different meaning. It is able to create niqabis'agency and reveal their power in the specific ways in which it could not be exposed in their offline sphere. Not only just the way niqabis could communicate but also to empowering their economy by doing business online.

\section{CONCLUSIONS}

The internet has open some then closed door to the expanding information of the bordered world to the borderless one to all kinds of people, including the niqabis women. Even though the daily activities of niqabis women is strictly limited and have been closed and private, the online media gives them fresh air to breath in. By supplying them freedom of speech and expression, the internet has successfully brings salafi niqabi women to experience the sense of liberty which other people has experienced in Indonesian democratic society. Through the internet, niqabis has been facilitated to exercise their agency in spreading their ideology in broader society, empowering their economy, as well as expressing their everyday activities which is limited to be published and seen in their offline world. In this point, though it is does not show the real democratic nature in a common understanding, it shows the agency and power of niqabi women as well as their freedom of talk and expression in different sense. 


\section{REFERENCES}

Ali, Mohamed Bin. 2016. The Roots of Religious Extremism: Understanding the Salafi Doctrine of AlWala' Wal Bara'. London: Imperial College Press.

Alimi, M. Yasir. 2014. Local repertoires of reasoning and the Islamist movement in post-authoritarian Indonesia. Journal Indonesia and the Malay World, Volume 42, Issue 122, 24-42.

Al-Rasheed, Madawi. 2002. A History of Saudi Arabia. Cambridge: Cambridge University Press.

Amghar, Samir. 2007. Salafism and Radicalisation of Young European Muslims. 38-51 in Samir Amghar et.al. (Eds.), European Islam: Challenges for Public Policy and Society. Brussels: Centre for European Policy Studies.

Armborst, Andreas. 2009. A Profile of Religious Fundamentalism and Terrorist Activism. Defence Against Terrorism Review, Vol. 2, No. 1, 51-71.

Bruinessen, Martin Van. 2017. Genealogies of Islamic radicalism in post-Suharto Indonesia. South East Asia Research, Vol. 10, No. 2,, 117-154.

Bruinessen, Martin Van. (Ed.). 2014. Conservative Turn: Islam Indonesia dalam Ancaman Fundamentalisme. Bandung: Mizan Media Utama.

Byman, Daniel \& Gold, Zack. 2012. The Salafi Awakening. The National Interest, Nol. 120 (July/August), 27-37.

Clandinin D.J. and Conelly, F.M. 2000. Narrative Inquiry: Experience and Story in Qualitative Research. San Fransisco: Jossey Bass.

Commins, David. 2006. The Wahhabi Mission and Saudi Arabia. London: I.B. Tauris

Fandy, Mamoun. 2001. Saudi Arabia and the Politics of Dissent. New York: Palgrave

Ghony, D,M. Almanshur,F. 2012. Metodologi Penelitian Kualitatif, Ar-RuzzMedia. Yogyakarta.

Hasan, Noorhaidi. 2006. Laskar Jihad Islam, Militancy, and the Quest for Identity in Post-Order Indonesia. Ithaca: Cornell Southeast Asia Program Publications

Hasan, Noorhaidi. 2007. The Salafi Movement in Indonesia: Transnational Dynamics and Local Development. Comparative Studies of South Asia, Africa and the Middle East, Vol. 27, No. 1.

Hasan, Noorhaidi. 2011. Salafi Madrasas and Islamic Radicalism in Post-New Order Indonesia, in Kamaruzzaman Bustamam-Ahmad \& Patrick Jory (eds), Islamic Studies and Islamic Education in Contemporary Southeast Asia. Malaysia: Yayasan Ilmuwan.

Hegghammer, Thomas. 2009. Jihadi-Salafis or Revolutionaries? On Religion and Politics in the Study of Militant Islamism. pp. 244-266, in Roel Meijer (ed.), Global Salafism Islam's New Religious Movement. New York: Columbia University Press.

Inge, Anabel. 2017. The Making of Salafi Muslim Women: Paths to Conversion. New York: Oxford University Press.
Iqbal, Asep Muhamad. 2017. Cyber-Activism and the Islamic Salafi Movement in Indonesia, PhD Thesis, Murdoch University.

Jahroni, Jajang. 2015. The Political Economy of Knowledge: Salafism in post Soeharto urban Indonesia, Graduate School of Arts and Sciences Dissertation. Boston University.

Jannah, Anassoffa'ul, Konstruksi Identitas Kolektif Perempuan gerakan Salafi: Studi di Masjid ibnu Sina Fakultas Kedokteran UGM Yogyakarta. Skripsi, UIN Sunan Kalijaga.

Lauzière, Henri. 2016. The Making of Salafism: Islamic Reform in The Twentieth Century. New York: Columbia University Press.

Lia, Brynjar. 2007. Architect of Global Jihad: The Life of al-Qaida Strategist Abu Mus'ab Al-Suri. London and New York: Hurst and Columbia University Press.

Meijer, Roel (ed.). 2009. Global Salafism Islam's New Religious Movement. New York: Columbia University Press.

Merlins, Reti Reka. 2010. Pemaknaan Kesetaraan Gender Pada Perempuan dalam Komunitas Islam: Studi Pada Komunitas Salafi, Wahdah Islamiyah, dan Hizbut Tahrir", Thesis, Sociology Department Gadjah Mada University.

Nisa, Efa F. 2012. Cadari of Wahdah Islamiyah: Women as Dedicated Actors of Ultra-conservatism, Intersections: Gender and Sexuality in Asia and the Pacific, Issue 30, November.

Nisa, Efa F. 2013. The Internet Subculture of Indonesian Face- Veiled Women, International Journal of Cultural Studies, 1-15.

Porter, Donald.J. 2002. Citizen participation through mobilization and the rise of political Islam in Indonesia, Journal The Pacific Review, Volume 15, 2002 - Issue 2, 201-224.

Riddel, P.G. 2002. The Diverse Voices of Political Islam in Post-Suharto Indonesia. Journal Islam and Christian-Muslim Relations, Volume 13, Issue 1, 6584.

Roy, Olivier. 2004. Globalised Islam: The Search for a New Ummah. London: C Hurst \& Co Publishers Ltd.

Sabrina, Firza. 2014. Perempuan dan Media: Perempuan Salafi dan Aksesibilitas Media (Studi Etnografi Pada Perempuan Salafi di Wisma Qaanitah, Yogyakarta). Skripsi, Department of communication Science, Gadjah Mada University.

Sakai, Minako. \& Fauzia, Amalia. 2014. Islamic orientations in contemporary Indonesia: Islamism on the rise. Asian Ethnicity, Vol. 15, No. 1, 41-61.

Sedgwick, Mark. 2012. Salafism, the Social and the Global Resurgence of Religion. Comparative Islamic Studies, 8, 1-2, 57-69.

Tarawiyah, Siti, "Behind the Burqa: a study on ideology and social role of salafi women in South Kalimantan", Conference Proceedings Annual International Conference on Islamic Studies (AICIS), pp. 14851500 . 
Teitelbaum, Joshua. 2000. Holier than Thou: Saudi Arabia's Islamic Opposition. WashingtonDC: The Washington Institute for Near East Policy.

Turner, John. A. 2014. Religious Ideology and the Roots of the Global Jihad: Salafi Jihadism and International Order. UK: Palgrave Macmillan. 